\title{
THE ACIDIFYING EFFECT OF RUBIDIUM IN NORMAL AND POTASSIUM-DEFICIENT ALKALOTIC RATS ${ }^{1}$
}

\author{
By ARNOLD S. RELMAN, ARLENE M. ROY, AND WILLIAM B. SCHWARTZ
}

(From the Evans Memorial, Massachusetts Memorial Hospitals, and the Department of Medicine, Boston University School of Medicine; and from the New England Center Hospital, and the Department of Medicine, Tufts College Medical School, Boston, Mass.)

(Submitted for publication October 20, 1954; accepted November 29, 1954)

Rubidium, element number 37 , is an alkalimetal found in small quantities in the earth's crust, and in trace amounts in human tissues (1). Listed immediately below potassium in the Group I elements of the periodic table, rubidium possesses many of potassium's physical, chemical, and physiological properties. These two elements have qualitatively similar effects on the contraction of the isolated heart (2), on the depolarization of nerve or muscle preparations $(3,4)$, and on the activity of certain intracellular enzyme systems $(5,6)$. The distribution of rubidium in human tissues resembles that of potassium $(1,7)$, and rubidium has been shown to be concentrated in certain plant cells $(8)$ and in animal tissues $(9,10)$ with great rapidity. It has also been reported that addition of rubidium to a potassium-free diet will prevent the development in rats of most of the histological changes associated with potassium depletion (11).

The central purpose of the present work was to compare the effects of rubidium and potassium ions on acid-base balance in normal and in potassium-depleted rats. When given an alkaline-ash, potassium-deficient diet, rats develop an alkalosis (12), which can be rapidly corrected by administration of potassium chloride (13). The present data indicate that rubidium has an acidifying effect on extracellular fluid at least equal to, and under some circumstances clearly greater than, that of potassium.

\section{METHODS AND MATERIALS}

Male albino rats of the Sprague-Dawley strain were used in all experiments. Four types of experiments were carried out. In the first, the chloride salts of sodium,

1 This study was supported in part by grants from the National Institute of Arthritis and Metabolic Diseases and the National Heart Institute of the National Institutes of Health, U. S. Public Health Service. potassium, and rubidium were administered intraperitoneally in equivalent amounts for a period of six days to normal growing rats on a Purina Lab Chow diet. In the second experiment, weanlings were made alkalotic and potassium-deficient by the administration of an alkaline-ash, potassium-free diet, and then treated over a six-day period with equivalent amounts of sodium chloride, rubidium chloride, and potassium chloride. In a third experiment, a large quantity of rubidium chloride or potassium chloride was given in a period of one day to potassium-deficient alkalotic rats. In the final experiment, potassium-deficient alkalotic rats were nephrectomized and then injected with sodium chloride, rubidium chloride or potassium chloride.

Animals were kept in separate cages. Food and water were allowed ad libitum. All injections were made intraperitoneally. Blood specimens were taken directly from the abdominal aorta in oiled heparinized syringes after the animal had been lightly anesthetized with Sodium Amytald (20 mg. per $100 \mathrm{gm}$.). The pH of whole blood was determined anaerobically at room temperature in a research model Cambridge $\mathrm{pH}$ meter and corrected to $37^{\circ} \mathrm{C}$. (.01 pH unit per degree). It should be noted that blood $\mathrm{pH}$ in rats is subject to relatively large fluctuations due to acute changes in respiratory activity immediately prior to and during exsanguination. For this reason, $\mathrm{pH}$ data are less reliable indices of acid-base disturbances in the rat than are determinations of total $\mathrm{CO}_{2}$ content (13). Total $\mathrm{CO}_{2}$ content of plasma was measured by standard manometric technique. The chloride content of plasma was determined by Volhard titration. Sodium and potassium were determined with a flame photometer. No analyses for rubidium or potassium could be done in the rats given rubidium since these ions could not be quantitatively determined in the presence of each other by any of the commercial flame photometers available to us, or by any of the standard titrimetric or gravimetric procedures suitable for analysis of either ion separately.

The details of each experiment follow :

Experiment I (Table I): Normal 90 to $100 \mathrm{gm}$. rats were divided into four groups. All animals were allowed to eat Purina Lab Chow and to drink tap water ad libitum. Those in Group 1 were controls and received no injections. Animals in Group 2 were given daily intraperitoneal injections of sodium chloride solution, Group 3 
TABLE I*

Effect of chronic administration of $\mathrm{NaCl}, \mathrm{KCl}$, and $\mathrm{RbCl}$ to normal rats

\begin{tabular}{lcccc}
\hline \hline & & & \multicolumn{2}{c}{ Plasma } \\
\cline { 4 - 5 } \multicolumn{1}{c}{ Group } & $\begin{array}{c}\text { No. } \\
\text { rats }\end{array}$ & $\begin{array}{c}\text { Blood } \\
\text { pH }\end{array}$ & $\begin{array}{c}\text { CO } \\
m M / L .\end{array}$ & $\begin{array}{c}\text { Potassium } \\
m E Q . / L .\end{array}$ \\
\hline 1. Control & 11 & $7.49 \pm 0.05$ & $26.2 \pm 1.92$ & $4.28 \pm 0.09$ \\
2. $\mathrm{NaCl}$ & 13 & $7.45 \pm 0.04$ & $25.5 \pm 1.92$ & $4.33 \pm 0.35$ \\
3. $\mathrm{KCl}$ & 11 & $7.45 \pm 0.04$ & $25.3 \pm 1.71$ & $4.40 \pm 0.32$ \\
4. $\mathrm{RbCl}$ & 13 & $7.50 \pm 0.04$ & $22.5 \pm 1.38$ & -
\end{tabular}

* In this table, and in all subsequent tables, values for blood analyses are given as the mean \pm the standard deviation.

received potassium chloride solution and Group 4 rubidium chloride solution. Each animal received $3 \mathrm{mEq}$. per $\mathbf{k g m}$. of the respective salt as a $200 \mathrm{mEq}$. per $\mathrm{L}$. solution, and the injections were continued for six consecutive days so that a total of $18 \mathrm{mEq}$. per $\mathrm{kgm}$. was administered. Animals were sacrificed on the seventh day, approximately 24 hours after Groups 2, 3, and 4 had received their last injection.

Experiment II (Table II) : Ninety to one hundred gm. rats were given a potassium-free diet (Groups 2-6) identical in composition with that used by Cotlove, Holliday, Schwartz, and Wallace (14) except that the inorganic salt content was altered by removing calcium carbonate, dibasic sodium phosphate, and sodium chloride from the salt mixture and substituting a mixture of monobasic and dibasic calcium phosphate in a molar ratio of 1:2. This produced no change in the final calcium and phosphorus content (approximately 0.6 per cent each). Sodium, chloride, and bicarbonate ions were added to the diet in the drinking water, which contained $100 \mathrm{mEq}$. per L. sodium chloride and $50 \mathrm{mEq}$. per $\mathrm{L}$. sodium bicarbonate. This provided an acid-ash, potassium-free diet, with adequate quantities of sodium and chloride and all the alkali provided entirely in the drinking water. ${ }^{2}$ Over the entire range of solid (acid-ash) and water (alkaline-

2 These changes were made in order to facilitate use of this diet in other experiments in which the relative quantities of dietary alkali (bicarbonate) and chloride were varied. ash) intakes observed in our rats, the net intake on this regime was always alkaline. A control group of animals (Group 1) was given the same diet and drinking water, but potassium bicarbonate, $87 \mathrm{~mm}$. per $\mathrm{kgm}$. of diet, was added to their food.

At the end of sixteen days, some of the potassiumdeficient rats were sacrificed (Group 2) and the rest of them were divided into four groups. All these latter animals were continued on the potassium-free diet, but they were given only distilled water to drink, thus removing all dietary bicarbonate, sodium, and chloride, and thereby converting the net intake to acid-ash. One group (Group 3) was given no other therapy. Another group (Group 4) was injected intraperitoneally with sodium chloride solution, another with potassium chloride (Group 5), and the last with rubidium chloride (Group 6), all in a dosage of $5 \mathrm{mEq}$. per $\mathrm{kgm}$. per day for six consecutive days, using a $200 \mathrm{mEq}$. per $\mathrm{L}$. solution. All of these animals, as well as the control group (Group 1) taking a complete diet, were sacrificed on the 23rd day, approximately 24 hours after Groups 4, 5, and 6 had received their last injection.

Experiment III (Table III): A group of 80 to $90 \mathrm{gm}$. rats was made alkalotic and potassium-deficient by 18 days of feeding with the potassium-free, alkaline-ash diet used by Cotlove, Holliday, Schwartz, and Wallace (14), and some (Group 1) were sacrificed at the end of this time. The remaining animals were then divided into two groups, one of which received intraperitoneal injections of potassium chloride solution (Group 2) and the other, rubidium chloride solution (Group 3). A total of $18 \mathrm{mEq}$. per $\mathrm{kgm}$. was given in four equal doses during the 19th day, at a concentration of $100 \mathrm{mEq}$. per L. All animals in Groups 2 and 3 were sacrificed on the 20th day, approximately 18 hours after the last injection.

Experiment IV (Table IV): One hundred and fifty gm. rats were fed the diet used in Experiment II, with sodium chloride and sodium bicarbonate added to their drinking water, as before. A control group (Group 1), to whose diet potassium bicarbonate, $87 \mathrm{~mm}$. per $\mathrm{kgm}$. had been added, and a group of potassium-deficient animals (Group 2) were killed on the 15th day. The remainder of the potassium-deficient rats were nephrectomized on the 15th day under light Sodium Amytal anesthesia (20 mg. per $100 \mathrm{gm}$.), and then divided into four groups.

TABLE II

Effect of chronic administration of $\mathrm{NaCl}, \mathrm{KCl}$, and $\mathrm{RbCl}$ to $\mathrm{K}$-deficient alkalotic rats

\begin{tabular}{|c|c|c|c|c|}
\hline \multirow[b]{2}{*}{ Group } & \multirow[b]{2}{*}{$\begin{array}{l}\text { No. } \\
\text { rats }\end{array}$} & \multirow[b]{2}{*}{$\underset{\text { DH }}{\text { Blood }}$} & \multicolumn{2}{|c|}{ Plasma } \\
\hline & & & $\underset{m M / L}{\mathrm{CO}_{2}}$ & $\begin{array}{l}\text { Potassium } \\
m E q . / L .\end{array}$ \\
\hline $\begin{array}{l}\text { 1. K-added control } \\
\text { 2. K-deficient control } \\
\text { 3. K-deficient followed by removal of }\end{array}$ & $\begin{array}{l}14 \\
15\end{array}$ & $\begin{array}{l}7.41 \pm 0.02 \\
7.52 \pm 0.07\end{array}$ & $\begin{array}{l}26.2 \pm 1.65 \\
36.4 \pm 4.55\end{array}$ & $\begin{array}{l}4.04 \pm 0.26 \\
1.63 \pm 0.27\end{array}$ \\
\hline $\begin{array}{l}\text { alkali from drinking water } \\
\text { 4. Same as Group } 3,+\mathrm{NaCl} \\
\text { 5. Same as Group 3, +KCl } \\
\text { 6. Same as Group 3, +RbCl }\end{array}$ & $\begin{array}{r}9 \\
11 \\
15 \\
13\end{array}$ & $\begin{array}{l}7.50 \pm 0.05 \\
7.41 \pm 0.06 \\
7.41 \pm 0.05 \\
7.38 \pm 0.08\end{array}$ & $\begin{array}{l}28.9 \pm 4.69 \\
28.2 \pm 3.10 \\
26.9 \pm 2.65 \\
19.5 \pm 4.23\end{array}$ & $\begin{array}{c}1.59 \pm 0.20 \\
1.82 \pm 0.27 \\
3.58 \pm 0.65 \\
-\end{array}$ \\
\hline
\end{tabular}


TABLE II-A

$P$ values for $\mathrm{CO}_{2}$ data of Table $\mathrm{II}$ *

\begin{tabular}{|c|c|c|c|c|c|c|}
\hline & $\begin{array}{c}\text { Group } 1 \\
(x)=26.2 \\
m M / L .\end{array}$ & $\begin{array}{c}\text { Group 2 } \\
(x)=36.4 \\
m M / L .\end{array}$ & $\begin{array}{c}\text { Group } 3 \\
(x)=28.9 \\
m M / L .\end{array}$ & $\begin{array}{c}\text { Group } 4 \\
(\bar{x})=28.2 \\
m M / L .\end{array}$ & $\begin{array}{c}\text { Group } 5 \\
(x)=26.9 \\
m M / L .\end{array}$ & $\begin{array}{c}\text { Group } 6 \\
(x)=19.5 \\
m M / L .\end{array}$ \\
\hline $\begin{array}{l}\text { Group } 1 . \\
\mathrm{K} \text {-added control } \\
(\overline{\mathrm{x}})=26.2 \mathrm{mM} / L .\end{array}$ & & $<.01$ & N.S.* & N.S. & N.S. & $<.01$ \\
\hline $\begin{array}{l}\text { Group } 2 . \\
\text { K-deficient control } \\
\qquad(\overline{\mathrm{x}})=36.4 \mathrm{mM} / L .\end{array}$ & $<.01$ & & $<.01$ & $<.01$ & $<.01$ & $<.01$ \\
\hline $\begin{array}{l}\text { Group } 3 . \\
\text { K-deficient followed by removal of } \\
\text { alkali from drinking water } \\
(\bar{x})=28.9 \mathrm{mM} / L \text {. }\end{array}$ & N.S. & $<.01$ & & N.S. & N.S. & $<.01$ \\
\hline $\begin{array}{l}\text { Group } 4 . \\
\text { Same as Group } 3,+\mathrm{NaCl} \\
(\overline{\mathrm{x}})=28.2 \mathrm{mM} / L\end{array}$ & N.S. & $<.01$ & N.S. & & N.S. & $<.01$ \\
\hline $\begin{array}{l}\text { Group } 5 . \\
\text { Same as Group } 3,+\mathrm{KCl} \\
\quad(\overline{\mathbf{x}})-26.9 \mathrm{mM} / L\end{array}$ & N.S. & $<.01$ & N.S. & N.S. & & $<.01$ \\
\hline $\begin{array}{l}\text { Group 6. } \\
\text { Same as Group } 3,+\mathrm{RbCl} \\
(\overline{\mathrm{x}})=19.5 \mathrm{mM} / \mathrm{L} .\end{array}$ & $<.01$ & $<.01$ & $<.01$ & $<.01$ & $<.01$ & \\
\hline
\end{tabular}

$* \mathrm{P}>.05$.

One group (Group 3) was given no therapy and allowed no food or water. They were sacrificed four hours after nephrectomy. Three groups were injected with a total of $8 \mathrm{mEq}$. per $\mathrm{kgm}$. of sodium (Group 4), potassium (Group 5), or rubidium (Group 6). These cations were given in two equal doses at concentrations of $126 \mathrm{mEq}$. per L. as the chloride salt, together with $24 \mathrm{mEq}$. per $\mathrm{L}$. as the bicarbonate salt. ${ }^{3}$ The first dose was given immediately after nephrectomy and the second dose two hours later. The animals were sacrificed two hours after the second dose, i.e., four hours after nephrectomy. During this time they were allowed no food or water.

To determine the extent of uptake of the administered rubidium and potassium, the fluid remaining in the peritoneal cavity (usually 1 to $4 \mathrm{cc}$.) was analyzed for so-

TABLE III

Effect of acute administration of $\mathrm{KCl}+\mathrm{RbCl}$ to alkalotic, $K$-deficient rats

\begin{tabular}{lrcrcr}
\hline & & & \multicolumn{2}{c}{ Plasma } \\
\cline { 5 - 6 } \multicolumn{1}{c}{ Group } & $\begin{array}{c}\text { No. } \\
\text { rats }\end{array}$ & $\begin{array}{c}\text { Blood } \\
\mathbf{p H}\end{array}$ & & $\begin{array}{c}\mathrm{CO}_{2} \\
m M / L .\end{array}$ & $\begin{array}{c}\text { Potassium } \\
m E q . / L .\end{array}$ \\
\hline 1. K-deficient & & & & \\
$\quad$ control & 11 & $7.48 \pm 0.05$ & $34.1 \pm 3.94$ & $1.68 \pm 0.09$ \\
2. $\mathrm{KCl}$ & 7 & $7.40 \pm 0.04$ & $29.8 \pm 3.05$ & $4.17 \pm 1.10$ \\
3. $\mathrm{RbCl}$ & 5 & $7.37 \pm 0.03$ & $29.1 \pm 3.10$ & - \\
\hline
\end{tabular}

8 Bicarbonate was added, as in the experiments of Orloff, Kennedy, and Berliner (15), to minimize changes in $\mathrm{CO}_{2}$ content due solely to dilution by the volume of administered fluid. dium (and also for potassium in the animals given this cation) in several rats of each group. In all instances the concentrations of these cations in the peritoneal fluid were essentially equal to those in plasma. These results indicate cellular uptake of almost all the administered potassium, and uptake of at least the largest part of the administered rubidium.

\section{RESULTS}

\section{Experiment I: Chronic administration of sodium} chloride, potassium chloride, and rubidium chloride to normal rats

All the injected animals seemed to tolerate the various chloride salts without difficulty and all gained approximately the same amount of weight. The chemical data are summarized in Table I. It is seen that injections of sodium chloride and potassium chloride had no significant effect on blood $\mathrm{pH}$ or plasma content of carbon dioxide or potassium. The group treated with rubidium chloride showed a small reduction in plasma $\mathrm{CO}_{2}$ content which was statistically significant when referred to any of the other groups, including the

4 In the reporting of results, and in the subsequent discussion of the data, whenever a difference between two group means is said to be "significant," it will be understood that the t-test yields a value of " $p$ " less than .01 . 
TABLE IV

Effect of nephrectomy alome, and of nephrectomy $+\mathrm{NaCl}, \mathrm{KCl}$, and $\mathrm{RbCl}$ in alkalotic, $\mathrm{K}$-deficient rats

\begin{tabular}{|c|c|c|c|c|c|c|}
\hline \multirow[b]{2}{*}{ Group } & \multirow[b]{2}{*}{$\begin{array}{l}\text { No. } \\
\text { rats }\end{array}$} & \multirow[b]{2}{*}{$\underset{\text { pH }}{\text { Blood }}$} & \multicolumn{4}{|c|}{ Plasma } \\
\hline & & & $\mathrm{CO}_{\mathrm{m}}$ & $\underset{m E_{\ell} / L}{\mathrm{Na}}$ & $\underset{m E_{q_{0}} / L}{\mathrm{~K}}$ & $\underset{m E_{q .} / L}{\mathrm{Cl}}$ \\
\hline $\begin{array}{l}\text { 1. Normal diet } \\
\text { 2. K-deficient } \\
\text { 3. K-deficient + nephrectomy } \\
\text { 4. K-deficient + nephrectomy }+\mathrm{NaCl} \\
\text { 5. K-deficient + nephrectomy + } \mathrm{KCl} \\
\text { 6. K-deficient + nephrectomy + } \mathrm{RbCl}\end{array}$ & $\begin{array}{l}14 \\
22 \\
11 \\
20 \\
16 \\
17\end{array}$ & $\begin{array}{l}7.54 \pm .06 \\
7.58 \pm .08 \\
7.55 \pm .05 \\
7.60 \pm .07 \\
7.55 \pm .06 \\
7.54 \pm .05\end{array}$ & $\begin{array}{l}26.7 \pm 1.3 \\
37.6 \pm 3.8 \\
31.5 \pm 2.1 \\
29.5 \pm 3.1 \\
27.1 \pm 2.4 \\
25.7 \pm 4.3\end{array}$ & $\begin{array}{l}141.0 \pm 1.6 \\
142.2 \pm 2.3 \\
142.8 \pm 1.9 \\
143.7 \pm 2.9 \\
141.8 \pm 2.5 \\
141.9 \pm 3.8\end{array}$ & $\begin{array}{l}3.52 \pm .38 \\
1.75 \pm .34 \\
1.84 \pm .46 \\
1.79 \pm .23 \\
2.90 \pm .79 \\
-\end{array}$ & $\begin{array}{r}103.5 \pm 2.8 \\
90.2 \pm 2.3 \\
89.6 \pm 2.4 \\
96.7 \pm 4.6 \\
100.0 \pm 6.3 \\
104.5 \pm 5.9\end{array}$ \\
\hline
\end{tabular}

TABLE IV-A

$P$ values for $\mathrm{CO}_{2}$ data of Table IV

\begin{tabular}{|c|c|c|c|c|c|c|}
\hline & $\begin{array}{c}\text { Group 1 } \\
(x)=26.7 \\
m M / L .\end{array}$ & $\begin{array}{c}\text { Group } 2 \\
(x)=37.6 \\
m M / L .\end{array}$ & $\begin{array}{c}\text { Group } 3 \\
(\mathbf{x})=31.5 \\
m M / L .\end{array}$ & $\begin{array}{c}\text { Group } 4 \\
(\bar{x})=29.5 \\
m M / L .\end{array}$ & $\begin{array}{c}\text { Group } 5 \\
(x)=27.1 \\
m M / L .\end{array}$ & $\begin{array}{l}\text { Group } 6 \\
(x)=25.7 \\
m M / L .\end{array}$ \\
\hline $\begin{array}{l}\text { Group 1. } \\
\text { Normal diet } \\
(\bar{x})=26.7 \mathrm{mM} / L\end{array}$ & & $<.01$ & $<.01$ & $<.01$ & N.S. & N.S. \\
\hline $\begin{array}{l}\text { Group 2. } \\
\text { K-deficient } \\
(\bar{x})=37.6 m M / L .\end{array}$ & $<.01$ & & $<.01$ & $<.01$ & $<.01$ & $<.01$ \\
\hline $\begin{array}{l}\text { Group 3. } \\
\text { K-deficient + nephrectomy } \\
\quad(\bar{x})=31.5 \mathrm{mM} / L\end{array}$ & $<.01$ & $<.01$ & & N.S. & $<.01$ & $<.01$ \\
\hline $\begin{array}{l}\text { Group } 4 . \\
\text { K-deficient + nephrectomy }+\mathrm{NaCl} \\
(\bar{x})=29.5 \mathrm{mM} / L\end{array}$ & $<.01$ & $<.01$ & N.S. & & $\begin{array}{l}>.02 \\
<.03\end{array}$ & $<.01$ \\
\hline $\begin{array}{l}\text { Group } 5 . \\
\text { K-deficient + nephrectomy }+\mathrm{KCl} \\
\quad(\overline{\mathbf{x}})=27.1 \mathrm{mM} / L\end{array}$ & N.S. & $<.01$ & $<.01$ & $\begin{array}{l}>.02 \\
<.03\end{array}$ & & N.S. \\
\hline $\begin{array}{l}\text { Group } 6 . \\
\text { K-deficient + nephrectomy }+\mathrm{RbCl} \\
\quad(\overline{\mathrm{x}})=25.7 \mathrm{mM} / \mathrm{L}\end{array}$ & N.S. & $<.01$ & $<.01$ & $<.01$ & N.S. & \\
\hline
\end{tabular}

control. The mean $\mathrm{pH}$ of none of the treated groups was significantly different from the control, but as pointed out earlier, little weight should be attached to these findings.

Experiment II : Chronic administration of sodium chloride, potassium chloride, and rubidium chloride to potassium-deficient alkalotic rats

The chemical data are summarized in Table II. Sixteen days of a potassium-free diet, with alkali in the drinking water, resulted in a severe metabolic alkalosis with hypokalemia (Group 2). Mean $\mathrm{CO}_{2}$ content in this group was $36.4 \mathrm{mM}$ per L., approximately $10 \mathrm{mM}$ per L. higher than the controls. Removal of alkali from the drinking water and continuation of the now acid-ash, potassium-free intake for another six days (Group
3) produced a significant reduction in $\mathrm{CO}_{2}$ content to $28.9 \mathrm{mM}$ per L., but the mean potassium concentration was not significantly different from the sixteen-day alkalotic group.

Treatment for six days with a total of $30 \mathrm{mEq}$. per $\mathrm{kgm}$. of sodium chloride, combined with removal of sodium chloride and sodium bicarbonate from the drinking water (Group 4), had no more effect on mean $\mathrm{CO}_{2}$ content than the single maneuver of substituting distilled water for the alkaline drinking water. Removal of alkali from the water, combined with treatment with potassium chloride (Group 5), resulted in a mean $\mathrm{CO}_{2}$ content of $26.9 \mathrm{mM}$ per L., which was not significantly different from the normal controls (Group 1) or from either Group 3 or Group 4. Plasma potassium was restored to almost normal levels. 
The group of rats treated with rubidium chloride injections and removal of sodium chloride and sodium bicarbonate from their drinking water (Group 6) showed the largest reduction in mean $\mathrm{CO}_{2}$ content $(19.5 \mathrm{mM}$ per $\mathrm{L}$. \pm 4.23$)$. This value was significantly lower than that found in any of the other groups, including even the normal controls.

The " $\mathrm{p}$ " values for the differences among the mean $\mathrm{CO}_{2}$ contents of the various groups are listed in Table II-A.

The data on mean $\mathrm{pH}$ value showed relatively smaller changes than were observed in total $\mathrm{CO}_{2}$ content, but in general, the changes were in the same direction.

The general appearance of the animals in the potassium and rubidium groups was the same. These rats began to gain weight and behaved more normally than those in Groups 3 and 4, which continued to lose weight.

Experiment III: Acute administration of potassium chloride and rubidium chloride to alkalotic potassium-deficient rats

Table III presents the results of the experiment, in which $18 \mathrm{mEq}$. per $\mathrm{kgm}$. of potassium chloride or rubidium chloride was administered to alkalotic potassium-deficient rats over a 24 -hour period. This treatment produed an approximately equal fall in $\mathrm{CO}_{2}$ content in both groups. The differences between the untreated group and each of the treatment groups was significant at the 3 per cent level. Blood $\mathrm{pH}$ was reduced significantly and almost equally in both groups.

\section{Experiment IV: Acute administration of sodium chloride, potassium chloride, and rubidium chlo- ride to nephrectomized potassium-deficient alka- lotic rats}

Table IV summarizes the data from the nephrectomy experiment. Fourteen days on a potassium-deficient, alkaline-ash diet (Group 2) produced the expected rise in $\mathrm{CO}_{2}$ content (37.6 $\mathrm{mM}$ per L.), and fall in potassium (1.75 mEq. per L.) and chloride ( $90.2 \mathrm{mEq}$. per L.) concentration. Four hours after bilateral nephrectomy (Group 3) there was a significant drop in $\mathrm{CO}_{2}$ content to $31.5 \mathrm{mM}$ per L., but no significant change in chloride, sodium or potassium; bicarbo- nate had therefore been replaced by the anions of unmeasured endogenous acids.

Nephrectomy plus intraperitoneal administration of sodium chloride and bicarbonate (Group 4) effected a slight but not significant drop in $\mathrm{CO}_{2}$ content to $29.5 \mathrm{mM}$ per L., and a larger and significant rise in plasma chloride to $96.7 \mathrm{mEq}$. per L. Sodium and potassium concentrations were essentially unchanged.

Treatment of nephrectomized animals with equivalent amounts of potassium chloride and bicarbonate (Group 5) resulted in a further drop in $\mathrm{CO}_{2}$ content to $27.1 \mathrm{mM}$ per $\mathrm{L}$., which was now significantly lower than the $\mathrm{CO}_{2}$ content of the Group 3 animals and essentially equal to the $\mathrm{CO}_{2}$ in the normal animals. Chloride was slightly, though not significantly, higher than in the sodium-treated group, but sodium concentration was unchanged. As expected, plasma potassium was significantly higher than in any of the other potassium-deficient groups, but it was still below the normal level.

Administration of rubidium chloride and bicarbonate to nephrectomized rats (Group 6) produced the largest fall in $\mathrm{CO}_{2}$ content $(25.7 \mathrm{mM}$ per L.), and the greatest rise in chloride concentration (104.5 mEq. per L.). These mean values, which were essentially equivalent to the normal (Group 1), differed significantly from the comparable data in both the untreated nephrectomized rats (Group 3) and the rats treated with sodium chloride (Group 4), but they were not significantly different from the means in the potassium group.

Table IV-A summarizes the " $\mathrm{p}$ " values for the differences among mean $\mathrm{CO}_{2}$ contents in this experiment.

For the most part changes in $\mathrm{pH}$ tended to follow those in carbon dioxide, but they were usually small and not significant. Occasionally, $\mathrm{pH}$ and $\mathrm{CO}_{2}$ appeared to deviate (Table I, group 4, Table IV, group 4).

\section{DISCUSSION}

In acute studies rubidium appears to be as effective as potassium in its ability to correct the alkalosis of potassium-deficiency, but the results of more chronic administration of rubidium indicate that this cation is more than merely a physiological substitute for potassium in its influence on acid-base metabolism. Prolonged administration 
of rubidium chloride to normal or potassium-deficient alkalotic animals produces a distinct extracellular acidosis, with bicarbonate values significantly below those of normal controls or those of animals given equivalent amounts of sodium or potassium chloride.

In potassium-deficient alkalotic animals, cellular accumulation of administered potassium is associated with displacement of intracellular hydrogen ions and subsequent reduction in extracellular bicarbonate concentration $(13,15)$. Since there is evidence that animal tissues can also accumulate large quantities of administered rubidium ions $(9,16)$, it is reasonable to assume that the acidifying effects of rubidium in the present experiments were accomplished, at least in part, by a similar displacement of cellular hydrogen.

In the nephrectomy experiment exchange of rubidium for hydrogen was probably the major factor in the fall in bicarbonate concentration. Other possible explanations seem unlikely. Cellular uptake of administered cation with bicarbonate (15) could not account for more than a small moiety of the rubidium estimated to have penetrated cells. Cellular extrusion of molecular acids seems unlikely because the plasma concentration of unmeasured anions (estimated by the difference between sodium and the sum of $\mathrm{CO}_{2}$ and chloride) was reduced rather than increased. Dilution of extracellular fluid by the volume of administered rubidium chloride solution would account for a fall of only 1 to $2 \mathrm{mM}$ per $\mathrm{L}$. in plasma $\mathrm{CO}_{2}$ content, which was the change observed in the group treated with sodium chloride.

In the chronic experiments, extrusion of intracellular hydrogen was probably also the primary mechanism for reduction of extracellular bicarbonate, but the fall in bicarbonate to sub-normal levels in the rubidium animals requires further explanation. Compared to potassium, rubidium may be more slowly excreted from the body and hence penetrate cells to a greater extent ; it may be preferentially taken up by muscle cells, or in some manner it may displace more intracellular hydrogen and less intracellular sodium than does an equivalent amount of potassium. On the other hand, the acidifying action of rubidium in the chronic experiments, particularly with the normal animals, may partly be ascribable to an effect of the cation on renal tubular transport of bicarbonate. There is evidence (17) that an excess of potassium ions reduces bicarbonate reabsorption and tends thereby to lower plasma bicarbonate. Conceivably rubidium might act in a similar, though more effective, manner. Evaluation of such speculations would require urine or tissue analyses or balance studies, all of which were beyond the scope of the present studies.

The present experiments not only suggest that replacement of intracellular cation by rubidium is as effective as replacement by potassium in the abolition of extracellular alkalosis, but they also demonstrate that the latter state may be ameliorated merely by the addition of acid, without restoration of normal cellular cation composition. It is a common clinical aphorism that alkalosis associated with potassium deficiency is "resistant" to any therapy other than replacement of the intracellular cation. However, in Experiment II (Group 3, Table II), it was possible to lower plasma bicarbonate to a value not significantly higher than the normal controls (Group 1) or the potassium-treated group (Group 5) simply by removing alkali from the drinking water and allowing the animals to continue ingestion of an acid-ash diet for six days. These animals received no potassium at any time during the experiment, and their final mean plasma potassium concentration was identical with that of the untreated potassium-deficient alkalotic group (Group 2).

The effects of acid also explain why, in Experiments II and IV, potassium does not appear to be much more effective than sodium in the correction of potassium-deficiency alkalosis. In these experiments an acid-ash intake (Experiment II) or the accumulation of endogenous acids after nephrectomy (Experiment IV) had reduced blood $\mathrm{CO}_{2}$ content in the sodium treated animals so nearly to normal that treatment with potassium could not be expected to have more than a slight additional effect.

\section{SUMMARY AND CONCLUSIONS}

1. Acute administration of rubidium chloride to potassium-deficient alkalotic rats is as effective in reducing extracellular bicarbonate concentration as the administration of equivalent amounts 
of potassium chloride. The data suggest that rubidium, like potassium, exerts its acidifying effect by exchanging for intracellular hydrogen.

2. Administration of rubidium chloride for six days to normal or potassium-deficient alkalotic rats produces a metabolic acidosis, while equivalent amounts of potassium do not lower bicarbonate concentrations below normal levels. Possible mechanisms by which rubidium produces metabolic acidosis are discussed.

3. Alkalosis associated with potassium depletion can be corrected without administration of intracellular cation simply by increasing the ratio of acid to alkali in the diet.

\section{REFERENCES}

1. Sheldon, J. H., and Ramage, H., A spectrographic analysis of human tissues. Biochem. J., 1931, 25, 1608.

2. Ringer, S., An investigation regarding the action of rubidium and caesium salts compared with the action of potassium salts on the ventricle of the frog's heart. J. Physiol., 1883, 4, 370.

3. Feng, T. P., and Liu, Y. M., The concentration-effect relationship in the depolarization of amphibian nerve by potassium and other agents. J. Cell. \& Comp. Physiol., 1949, 34, 33.

4. Sandow, A., and Mandel, H., Effects of potassium and rubidium on the resting potential of muscle. J. Cell. \& Comp. Physiol., 1951, 38, 271.

5. MacLeod, R. A., and Snell, E. E., The effect of related ions on the potassium requirement of lactic acid bacteria. J. Biol. Chem., 1948, 176, 39.

6. Von Korff, R. W., The effects of alkali metal ions on the acetate activating enzyme system. J. Biol. Chem., 1953, 203, 265.

7. Zipser, A., and Freedberg, A. S., The distribution of administered radioactive rubidium $\left(\mathrm{Rb}^{\mathrm{s}}\right)$ in nor- mal and neoplastic tissues of mice and humans. Cancer Research, 1952, 12, 867.

8. Brooks, S. C., The intake of radioactive isotopes by living cells. Sympos. Quant. Biol. (Cold Spring Harbor), 1940, 8, 171.

9. Mitchell, P. H., Wilson, J. W., and Stanton, R. E., The selective absorption of potassium by animal cells. II. The cause of potassium selection as indicated by the absorption of rubidium and cesium. J. Gen. Physiol., 1921, 4, 141.

10. Love, W. D., Romney, R. B., and Burch, G. E., A comparison of the distribution of potassium and exchangeable rubidium in the organs of the dog, using rubidium ${ }^{\text {es }}$. Circulation Research, 1954, 2, 112.

11. Follis, R. H., Jr., Histological effects in rats from adding rubidium or cesium to a diet deficient in potassium. Am. J. Physiol., 1943, 138, 246.

12. Darrow, D. C., Schwartz, R., Iannucci, J. F., and Coville, F., The relation of serum bicarbonate concentration to muscle composition. J. Clin. Invest., 1948, 27, 198.

13. Cooke, R. E., Segar, W. E., Cheek, D. B., Coville, F. E., and Darrow, D. C., The extrarenal correction of alkalosis associated with potassium deficiency. J. Clin. Invest., 1952, 31, 798.

14. Cotlove, E., Holliday, M. A., Schwartz, R., and Wallace, W. M., Effects of electrolyte depletion and acid-base disturbance on muscle cations. Am. J. Physiol., 1951, 167, 665.

15. Orloff, J., Kennedy, T. J., Jr., and Berliner, R. W., The effect of potassium in nephrectomized rats with hypokalemic alkalosis. J. Clin. Invest., 1953, 32, 538.

16. Heppel, L. A., and Schmidt, C. L. A., Studies on the potassium metabolism of the rat during pregnancy, lactation, and growth. Univ. California Publ., Physiol., 1938, 8, 189.

17. Roberts, K. E., Magida, M. G., and Pitts, R. F., Relationship between potassium and bicarbonate in blood and urine. Am. J. Physiol., 1953, 172, 47.

\section{ANNOUNCEMENTS OF MEETINGS}

The 47th Annual Meeting of the American Society for Clinical Investigation will be held in Atlantic City, N. J., on Monday, May 2, 1955, with headquarters at the Chalfonte-Haddon Hall. The scientific session will begin at 9 a.m. at the Steel Pier Theater.

The annual meeting of the Association of American Physicians will be held at the Steel Pier Theater on Tuesday, May 3, and at the Chalfonte-Haddon Hall on Wednesday morning, May 4, 1955. 